\title{
EFEK ANTIDIARE EKSTRAK ETANOL DAUN PARIJOTO (Medinilla speciosa Blume) PADA MENCIT JANTAN GALUR BALB/C
}

\author{
Yance Anas $^{1 *)}$, Desi Rakhmawati ${ }^{2)}$, Layyinatul Fuadah ${ }^{2)}$ dan Nola Carina Rahayu ${ }^{2)}$ \\ ${ }^{1)}$ Bagian Farmakologi dan Farmasi Klinik Fakultas Farmasi Universitas Wahid Hasyim \\ 2) Program Studi S1 Farmasi Fakultas Farmasi Universitas Wahid Hasyim \\ *E-mail :yance.apt@ gmail.com
}

\section{INTISARI}

Parijoto adalah salah satu tanaman langka di Indonesia dan daunnya secara tradisional telah digunakan untuk mengobati diare oleh masyarakat di daerah Kabupaten Kudus, Indonesia. Daun parijoto juga telah terbukti mengandung senyawa aktif tanin dan flavonoid yang diduga kuat berkahasiat sebagai antidiare. Penelitian ini bertujuan untuk membuktikan efek antidiare ekstrak etanol daun parijoto (EEDP) pada mencit jantan galur Balb/C yang diinduksi dengan castor oil dan mengungkap mekanisme antidiarenya melalui uji antimotilitas dan antisekretori.

EEDP dibuat dengan metode maserasi. Efek antidiare tiga peringkat dosis EEDP (500, 1.000 dan 2.000) $\mathrm{mg} / \mathrm{Kg}$ BB diujikan pada mencit diare yang diinduksi castor oil. Sementara itu, efek antimotilitas dan antisekretori EEDP dilakukan dengan metode transit intestinal dan castor oil induced enteropooling. Data yang dihasilkan dalam penelitian ini adalah onset diare, berat feses cair dan tidak berbentuk (selama 8 jam), rasio usus yang dilalui marker norit dan volume isi usus. Data-data tersebut dianalisis secara statistik pada taraf kepercayaan $95 \%$.

Hasil penelitian membuktikan bahwa EEDP terbukti mampu menunda terjadinya diare dan mengurangi terbentuknya feses cair-tidak berbentuk pada mencit jantan galur Balb/C yang diinduksi castor oil. Mekanisme antidiare EEDP juga terungkap dalam penelitian ini melalui efeknya sebagai antimotilitas dan antisekretori.

Kata kunci : ekstak etanol daun parijoto, antidiare, antimotilitas, antisekretori

\section{ABSTRACT}

Parijoto is one of a rare plant species in Indonesia, and its leaves have traditionally been utilized to treat diarrhea in the area of Kudus Regency, Indonesia. Parijoto leaves contain active compounds of tannin and flavonoid which have antidiarrheal properties. This investigation intends to demonstrate the antidiarrheal effect of parijoto leaf ethanol extract (EEDP) on male Balb/C mice castor oil-induced diarrheal and reveal its antidiarrheal mechanism through antimotility and antisecretory testing.

EEDP made by maceration method. The antidiarrheal effects of three series level EEDP (500; 1,000 and 2,000) $\mathrm{mg} / \mathrm{Kg} \mathrm{BB}$ tested on diarrhea mice induced by castor oil. Concurrently, the antimotility and antisecretory effects of EEDP investigated with the intestinal transit method and castor oil-induced enteropooling. The data in this study were the onset of diarrhea, the weight of liquid-formless stools (for 8 hours), the ratio of digestion tracts passed by norit markers, and the volume of intestinal contents. These data were analyzed statistically at the $95 \%$ confidence level.

The examination presumed that EEDP was able to respite the onset of diarrhea and diminish the formation of liquid-formless feces in male Balb/C mice induced by castor oil. The antidiarrheal mechanism of EEDP also exhibited in this study through its effects as antimotility and antisecretory.

Keywords: Parijoto leaf ethanol extract, antidiarrheal, antimotility, antisecretory 
*Corresponding author:

Yance Anas

Bagian Farmakologi dan Farmasi Klinik Fakultas Farmasi Universitas Wahid Hasyim

Jalan Menoreh Tengah X/22 Sampangan Semarang 50232 Telp (+6224) 8505680

Email: yance.apt@gmail.com

\section{PENDAHULUAN}

Diare adalah gangguan saluran pencernaan yang ditandai dengan peningkatan frekensi buang air besar dengan feses cair-lembek berair, lebih dari 3 kali dalam 24 jam (Beugerie dan Sokol, 2013). Walaupun merupakan bagian dari sistem pertahanan tubuh, diare akut masih merupakan penyebab utama kematian pada balita di seluruh dunia (525.000 kematian/tahun). Kebanyakan kasus kematian akibat diare pada balita terjadi di Negara berkembang (Farthing dkk., 2013). Penyebab diare akut yang paling sering (lebih dari $90 \%$ kasus) adalah infeksi bakteri, dengan gejala muntah, demam dan nyeri pada abdomen. Selain itu, diare dapat disebabkan oleh efek samping obat, keracunan, iskemia dan kondisi lain (Ahlquist dan Camilleri, 2005).

Salah satu kekayaan alam di Indonesia adalah tumbuhan parijoto dengan nama latin Medinilla speciosa Blume.(Gambar 1). Ciri khas yang terkenal dari tumbuhan ini adalah daun dan bunganya yang indah sehingga diakui sebagai salah satu genus tanaman hutan tercantik yang ada di dunia (Maria dkk., 2012). Di Indonesia, parijoto ditemukan tumbuh di Gunung Kinabalu di pulau Kalimantan, Pegunungan Muria, Kudus, Jawa Tengah dan area hutan Gunung Merapi, Yogyakarta (Anggana, 2011). Umumnya, parijoto tumbuh di ketinggian sekitar $1.700 \mathrm{~m}$ di atas permukaan laut (Hikosaka dkk., 2002). Masyarakat sekitar Pegunungan Muria percaya bahwa jika ibu hamil mengkonsumsi buah parijoto, maka akan mendapatkan bayi yang berparas tampan atau cantik (Mumpuni dkk., 2015). Selain itu, masyarakat juga percaya bahwa buah parijoto dapat meningkatkan kesuburan dan menjaga kesehatan ibu hamil (Anggana, 2011).

Daun parijoto telah digunakan secara tradisional oleh masyarakat sebagai obat diare, sariawan dan antiradang. Daun parijoto terasa masam, pahit, dan bersifat menyegarkan karena daunnya mengandung kardenolin, senyawa golongan saponin, tanin dan flavonoid (AHN, 2016). Senyawa aktif golongan tanin dan flavonoid dalam daun parijoto diduga bertanggung jawab terhadap klaim khasiat antidiare daun parijoto. Walaupun demikian, penggunaan daun parijoto dalam mengobati diare selama ini hanya berdasarkan pengalaman empiris masyarakat saja dan belum pernah dibuktikan khasiatnya melalui penelitian ilmiah (Wibowo dkk., 2012).

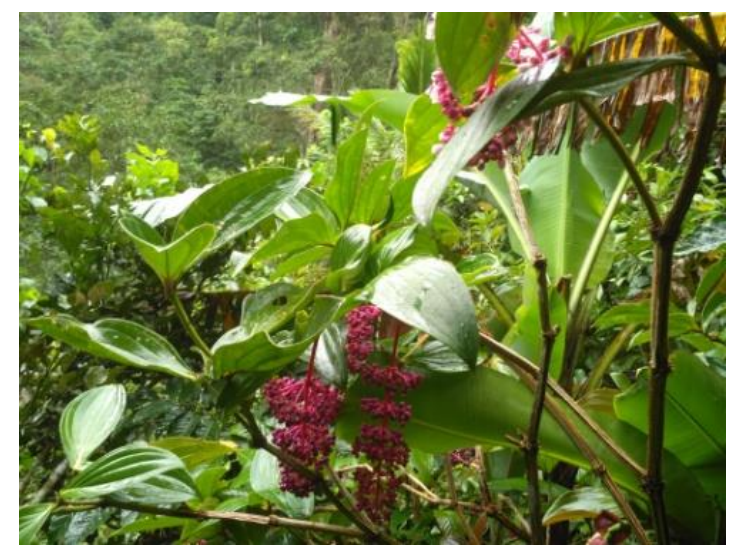

Gambar 1. Tanaman Parijoto

\section{METODE PENELITIAN \\ Bahan Penelitian}

Daun parijoto yang digunakan dalam penelitian ini adalah daun yang sudah tua (berwarna hijau), dan dipetik dari daerah Colo, Kecamatan Dawe, Kabupaten Kudus, Jawa Tengah, Indonesia. Etanol $70 \%$ (teknis, PT. Bratcho Chemika Tbk.) digunakan sebagai cairan penyari dalam 
pembuatan EEDP. Hewan uji yang digunakan adalah mencit jantan galur Balb/C, usia 2-3 bulan dengan berat badan 20-30 gram. Bahan-bahan lain yang digunakan dalam penelitian ini adalah loperamid $\mathrm{HCl}$ (PT. Nufarindo Semarang), Norit (PT. Indofarma Tbk.), larutan Normal Salin $\mathrm{NaCl}$ 0,9\% (PT. Widatra Bhakti), castor oil (PT. Brataco Chemika Tbk.), dan PGA (PT. Brataco Chemika Tbk.).

\section{Alat Penelitian}

Berbagai alat yang digunakan dalam membuat EEDP adalah oven (Memmert), blender (Maspion), ayakan 40 mesh, seperangkat alat maserasi dan vacuum rotary evaporator (Heidolp). Sementara itu, alat-alat lain yang digunakan untuk pengujian efek antidiare, antimotilitas dan antisekretori adalah spuit injeksi per-oral $(1 \mathrm{~mL})$, spuit injeksi 1,0 $\mathrm{mL}$ (Terrumo), timbangan binatang (ACIS), stop watch, kertas saring, kawat kassa, pinset, alat bedah, papan bedah, mistar dan tabung eppendorph.

\section{Jalannya Penelitian}

\section{Pembuatan ekstrak etanol buah parijoto}

Sebanyak $11 \mathrm{~kg}$ daun parijoto dicuci bersih, dipotong-potong dan dikeringkan meggunakan oven dengan pengaturan suhu $\pm 50^{\circ} \mathrm{C}$. Kadar air simplisia daun parijoto diukur menggunakan moisture balance. Ukuran partikel simplisia daun parijoto diperkecil dengan menggunakan blander dan diayak dengan ayakan 40 Mesh. Ekstraksi simplisia daun sambiloto dibuat dengan metode maserasi menggunakan lima liter etanol $70 \%$ sebagai cairan penyari. Pemekatan ekstrak dilakukan dengan rotary evaporator sehingga diperoleh ekstrak etanol daun parijoto (EEDP). selanjutnya, rendemen EEDP dihitung, disimpan dalam desikator dan digunakan untuk pengujian.

\section{Uji efek antidiare ekstrak etanol daun parijoto}

Metode uji efek antidiare EEDP dilakukan sesuai prosedur yang dilakukan Anas dkk. (2012). Sebanyak 30 ekor mencit jantan galur Balb/C yang memenuhi kriteria inklusi dikelompokkan secara acak ke dalam 6 kelompok perlakuan. Mencit kelompok I (kontrol negatif tanpa perlakuan) diberi suspensi PGA 3\% $20 \mathrm{~mL} / \mathrm{kgBB}$ dan $\mathrm{NaCl}$ 0,9\% $20 \mathrm{~mL} / \mathrm{kgBB}$. Mencit kelompok II (kontrol negatif dengan perlakuan) diberi suspensi PGA 3\% $20 \mathrm{~mL} / \mathrm{kgBB}$. Mencit kelompok III (kontrol positif) diberi loperamid $\mathrm{HCl}$ dosis $100 \mathrm{mg} / \mathrm{kgBB}$. Mencit kelompok IV, V, dan VI diberi perlakuan dengan EEDP $(500,1.000$, dan 2.000) $\mathrm{mg} / \mathrm{kgBB}$. Enam puluh menit setelah pemberian sediaan uji, mencit kelompok II-VI diberikan perlakuan 1,0 mL castor oil per-oral, kemudian diletakkan pada kandang plastik ukuran $18 \times 23 \mathrm{~cm}$ yang sebelumnya telah dialasi dengan kawat kassa dan dilapisi dengan kertas saring. Selanjutnya, data onset terjadinya diare dihitung ketika mencit pertama kali mengeluarkan feses cair-tidak berbentuk. Selain itu, data berat feses cair-tidak berbentuk diamati tiap 30 menit selama 8 jam. Persentase efek antidiare EEDP dihitung dengan menggunakan persamaan (1) yang merujuk pada penelitian yang dilakukan oleh Anas dkk., (2012):

$$
\% \text { Efek Antidiare }=\frac{k-p}{k} \times 100 \%
$$

Keterangan :

$p$ : rata-rata berat feses cair dan tidak berbentuk mencit kelompok EEDP dan loperamid $\mathrm{HCl}$

$k$ : rata-rata berat feses cair dan tidak berbentuk mencit kelompok kontrol negatif dengan perlakuan

\section{Uji efek antimotilitas ekstrak etanol daun parijoto}

Prosedur uji antimotilitas EEDP mengacu pada prosedur yang dilakukan oleh Anas dkk. (2012). Sebanyak 25 ekor mencit jantan galur Balb/C yang memenuhi kriteria inklusi dipuasakan selama 16-18 jam, dan tetap diberi air minum ad. libitum. Selanjutnya, mencit dibagi secara acak dalam 5 kelompok perlakuan. Kelompok I (kontrol negative) diberi perlakuan suspensi PGA 3\% 10 $\mathrm{mL} / \mathrm{KgBB}$, kelompok II (kontrol positif) diberi perlakuan loperamid $\mathrm{HCl} 1,5 \mathrm{mg} / \mathrm{KgBB}$, dan kelompok III, IV, V diberi perlakuan EEDP (500, 1.000, dan 2.000) $\mathrm{mg} / \mathrm{KgBB}$. Perlakuan sediaan uji pada mencit dilakukan secara peroral. Empat puluh lima menit Setelah perlakuan sediaan uji, semua mencit diberi perlakuan suspensi norit $10 \% 10 \mathrm{~mL} / \mathrm{KgBB}$ (p.o). Pada menit ke-65 setelah perlakuan sediaan uji, semua mencit dikorbankan. Usus mulai dari pylorus sampai rectum dikeluarkan secara hati-hati sampai teregang. Panjang usus yang dilalui market norit diukur dengan

JIFFK Vol. 16, No. 1, JUNI 2019, Hal. 28 - 35 
menggunakan mistar dan dibandingkan dengan panjang usus keseluruhan. Rasio jarak tempuh marker norit terhadap panjang usus seluruhnya dihitung dengan menggunakan persamaan (2) dan persentase efek antimotilitas EEDP dihitung dengan menggunakan persamaan (3):

$$
\mathbf{R}=\frac{N}{u}
$$

Keterangan:

$\mathrm{R}=$ rasio jarak tempuh marker norit

$\mathrm{N}=$ panjang usus yang dilewati marker norit

$\mathrm{U}=$ panjang usus keseluruhan

$$
\frac{K-P}{K} \times 100 \%
$$

Keterangan:

$\mathrm{K}=$ Rata- rata rasio panjang usus kelompok kontrol negatif

$\mathrm{P}=$ Rata-rata rasio panjang usus kelompok perlakuan (Loperamid dan EEDP)

\section{Uji efek antisekretori ekstrak etanol daun parijoto}

Uji efek antisekretori juga dilakukan menurut prosedur pengujian yang dilakukan oleh Anas dkk. (2012). Dua puluh lima ekor mencit jantan galur Balb/C yang memenuhi kriteria inklusi dipilih secara acak dan dibagi ke dalam lima kelompok perlakuan. Semua mencit yang digunakan dalam penelitian, dipuasakan terlebih dahulu selama 16 jam. Mencit kelompok I (kelompok kontrol negatif tanpa perlakuan) diberikan larutan $\mathrm{NaCl} 0,9 \%$ sebanyak $20 \mathrm{~mL} / \mathrm{kgBB}$ peroral. Mencit kelompok II diberikan PGA 3\% sebanyak $20 \mathrm{~mL} / \mathrm{gBB}$. Mencit kelompok III, IV dan V mendapat perlakuan EEDP $(500,1.000$, dan 2.000) $\mathrm{mg} / \mathrm{kgBB}$ peroral. Tiga puluh menit setelah pemberian sediaan uji, mencit kelompok II-V diberi 1,0 mL castor oil (p.o) dan dibiarkan 30 menit. Selanjutnya, semua mencit dikorbankan dengan cara dislokasi tulang belakang dan dilakukan pembedahan. Usus mencit dari phylorus sampai caecum dipotong dan isinya dikeluarkan lalu ditampung dalam tabung effendroph. Volume isi cairan usus diukur menggunakan spuit injeksi 1,0 mL.

\section{Analisis Data}

Semua data dalam penelitian ini dianalisis secara statistik menggunakan uji beda pada taraf kepercayaan $95 \%$. Sebelum dilakukan uji beda, normalitas dan tingkat homogenitas varian data diuji terlebih dahulu dengan menggunakan metode Kolsmogorof-Smirnoff dan Levene Test. Perbedaan nilai Rasio jarak tempuh yang dilalui marker norit dianalisis dengan menggunakan Anova satu jalan yang dilanjutkan dengan uji LSD. Sementara itu, perbedaan data onset terjadinya diare, berat feses cair-tidak berbentuk dan volume isi usus dianalisis dengan uji Kruskal-Wallis dan dilanjutkan dengan uji Mann-Whitney.

\section{HASIL DAN PEMBAHASAN \\ Kemampuan EEDP dalam Menunda Terjadinya Diare pada Mencit yang Diinduksi Castor Oil}

Perlakuan castor oil 1,0 mL mampu menginduksi terjadinya diare pada mencit galur Balb/C dalam waktu $(78 \pm 12)$ menit. Diare tersebut disebabkan karena adanya kandungan asam risinoleat dalam castor oil. Senyawa ini akan menyebabkan iritasi dan inflamasi pada dinding usus yang akan memicu biosintesis prostaglandin serta hipersekresi cairan elektrolit dan air (Katiyar dkk., 2015). Perubahan fungsi dan patofisiologis lain yang diakibatkan oleh aksi asam risinoleat pada dinding usus adalah meningkatnya kecepatan motilitas usus; perubahan permeabilitas membran, serta terganggunya absorpsi air, ion $\mathrm{Na}^{+}$, dan $\mathrm{K}^{+}$dalam kolon. Akibatnya, konsistensi feses akan menjadi berair/cair (Balaji dkk., 2012).

Hasil penelitian ini menyimpulkan bahwa EEDP $1.000 \mathrm{mg} / \mathrm{Kg}$ BB dan Loperamid $\mathrm{HCl} 100$ $\mathrm{mg} / \mathrm{Kg} \mathrm{BB}$ dapat menunda terjadinya diare pada mencit jantan galur Balb/C yang diinduksi $1,0 \mathrm{~mL}$ castor oil. Mencit yang mendapat perlakuan loperamid $\mathrm{HCl} 100 \mathrm{mg} / \mathrm{kgBB}$ dan ekstrak EEDP 1.000 $\mathrm{mg} / \mathrm{kgBB}$ memiliki onset terjadinya diare yang lebih lama bila dibandingkan dengan mencit kelompok kontrol negatif dengan perlakuan $(\mathrm{p}<0,05)$. Mencit yang mendapat perlakuan loperamid $\mathrm{HCl} 100 \mathrm{mg} / \mathrm{Kg} \mathrm{BB}$ dan EEDP $1.000 \mathrm{mg} / \mathrm{Kg}$ BB mengalami diare setelah (438 \pm 42$)$ menit dan 
$(144 \pm 26)$ menit dari perlakuan $1,0 \mathrm{~mL}$ castor oil. Onset terjadinya diare pada semua kelompok perlakuan dapat dilihat pada Gambar 2.

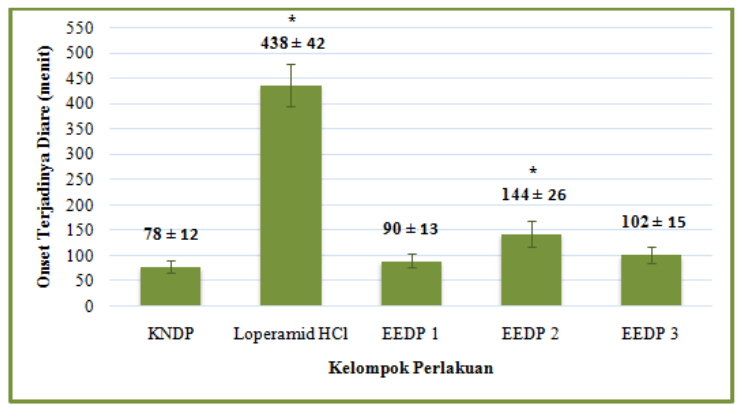

Gambar 2. Onset terjadinya diare pada semua kelompok perlakuan setelah perlakuan $1,0 \mathrm{~mL}$ castor oil . Keterangan :

KNDP : PGA $3 \% 20 \mathrm{~mL} / \mathrm{kgBB}+$ castor oil $1,0 \mathrm{~mL}$

Loperamid $\mathrm{HCl}$ : Loperamid $\mathrm{HCl} 100 \mathrm{mg} / \mathrm{kgBB}+$ castor oil $1,0 \mathrm{~mL}$

EEDP 1 : Ekstrak etanol daun parijoto $500 \mathrm{mg} / \mathrm{kgBB}+$ castor oil $1,0 \mathrm{~mL}$

EEDP 2 : Ekstrak etanol daun parijoto $1.000 \mathrm{mg} / \mathrm{kgBB}+$ castor oil $1,0 \mathrm{~mL}$

EEDP 3 : Ekstrak etanol daun parijoto $2.000 \mathrm{mg} / \mathrm{kgBB}+$ castor oil $1,0 \mathrm{~mL}$

( *): Hasil uji Mann-Whitney ada perbedaan yang bermakna dengan KNDP

\section{Efek Antidiare EEDP pada Mecit Jantan Galur Balb/C yang Diinduksi oleh Castor Oil}

Castor oil mampu memicu terjadinya diare/sekresi cairan dan elektrolit berlebih dalam usus sehingga akan memperlunak konsistensi feses dan menyebabkan terjadinya diare (Chitme dkk., 2004). Dalam penelitian ini, data berat feses cair-tidak berbentuk dikumpulkan dalam waktu delapan jam setelah pemberian $1,0 \mathrm{~mL}$ castor oil. Selama delapan jam pengamatan tersebut, mencit yang tidak mendapat perlakuan castor oil (KNTP) tidak mengalami diare. Sebaliknya, perlakuan $1,0 \mathrm{~mL}$ castor oil pada mencit kelompok KNDP menghasilkan feses cair-tidak berbentuk seberat $(0,1594 \pm 0,0216) \mathrm{g}$. Mencit yang mendapat perlakuan dengan loperamid $\mathrm{HCl} 100 \mathrm{mg} / \mathrm{Kg}$ BB dan tiga peringkat dosis EEDP memiliki rata-rata berat feses cair-tidak berbentuk yang lebih kecil bila dibandingkan dengan kelompok KNDP. Berat feses cair dan tidak berbentuk mencit yang mendapat perlakuan loperamid $\mathrm{HCl}$ adalah sebesar $(0,0857 \pm 0,0216) \mathrm{g}$, sedangkan perlakuan EEDP $(500,1000,2.000) \mathrm{mg} / \mathrm{kgBB}$ berturut-turut menghasilkan feses cair-tidak berbentuk seberat $(0,1179 \pm 0,0087 ; 0,1096 \pm 0,0126$ dan $0,0591 \pm 0,0035)$ g. Secara statistik, terdapat perbedaaan yang bermakna pada data rata-rata berat feses cair-tidak berbentuk kelompok KNDP dengan kelompok loperamid $\mathrm{HCl}$ dan EEDP $2.000 \mathrm{mg} / \mathrm{kgBB}(\mathrm{p}<0,05)$. Hasil penelitian ini membuktikan bahwa EEDP $2.000 \mathrm{mg} / \mathrm{kgBB}$ memiliki aktivitas sebagai antidiare. Persentase efek antidiare EEDP 2.000 $\mathrm{mg} / \mathrm{kgBB}$ dan loperamid $\mathrm{HCl} 100 \mathrm{mg} / \mathrm{Kg}$ BB berturut-turut adalah sebesar 62,94\% dan 46,25\%. Rata-rata berat feses cair-tidak berbentuk pada semua kelompok perlakuan dapat dilihat pada gambar 3 .

\section{Efek Antimotilitas EEDP pada Mencit Jantan Galur Balb/C dengan Metode Transit intestinal}

Efek antimotilitas EEDP diuji dengan metode transit intestinal yang menggambarkan kemampuan sediaan uji dalam menghambat peristaltik usus mencit. Data penelitian yang diukur adalah rasio jarak usus yang ditempuh oleh marker norit terhadap panjang usus keseluruhan dalam waktu 20 menit (R) (Sarin dan Bafina, 2012; Komal dan Rana, 2013). Hasil penelitian menunjukkan $\mathrm{R}$ mencit yang mendapat perlakuan EEDP (500, 1.000 dan 2.000) $\mathrm{mg} / \mathrm{Kg}$ BB dan Loperamid 1,5 mg/Kg BB lebih kecil dari pada R kelompok kontrol negatif $(\mathrm{p}<0,05)$. Oleh karena itu, penelitian ini menyimpulkan bahwa salah satu mekanisme antidiare EEDP adalah sebagai antimotilitas. EEDP (500-2.000) $\mathrm{mg} / \mathrm{Kg}$ BB mampu menghambat peristaltik usus mencit jantan galur Balb/C sebesar $(22,45-44,36) \%$. Rata-rata $\mathrm{R}$ pada semua kelompok perlakuan dan persentase efek antimotilitas EEDP dan Loperamid dapat dilihat pada Tabel I. 


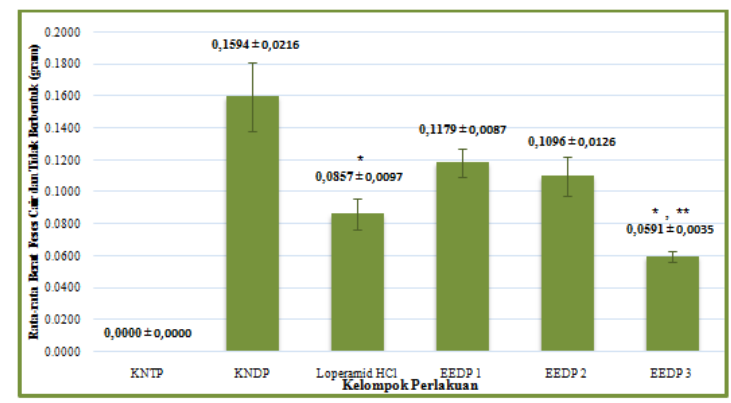

Gambar 3. Rata-rata berat feses cair-tidak berbentuk semua kelompok perlakuan setelah perlakuan $1,0 \mathrm{~mL}$ castor oil. Keterangan :

KNTP : $\quad$ PGA $3 \% 20 \mathrm{~mL} / \mathrm{kgBB}+\mathrm{NaCl} 20 \mathrm{~mL} / \mathrm{kgBB}$

KNDP : $\quad$ PGA 3\% $20 \mathrm{~mL} / \mathrm{kgBB}+$ castor oil 1,0 mL

Loperamid $\mathrm{HCl}$ : $\quad$ Loperamid $\mathrm{HCl}$ dosis $100 \mathrm{mg} / \mathrm{kgBB}+$ castor oil $1,0 \mathrm{~mL}$

EEDP 1 : Ekstrak etanol daun parijoto $500 \mathrm{mg} / \mathrm{kgBB}+$ castor oil $1,0 \mathrm{~mL}$

EEDP 2 : Ekstrak etanol daun parijoto $1000 \mathrm{mg} / \mathrm{kgBB}+$ castor oil $1,0 \mathrm{~mL}$

EEDP 3 : Ekstrak etanol daun parijoto $2000 \mathrm{mg} / \mathrm{kgBB}+$ castor oil $1,0 \mathrm{~mL}$

(*) : Hasil uji Mann-Whitney menunjukkan adanya perbedaan yang bermakna dengan rata-rata berat feses cair dan tidak berbentuk kelompok KNDP

(**) : Hasil uji Man-Whitney menunjukkan adanya perbedaan yang bermakna dengan rata-rata berat feses cair-tidak berbentuk dengan kelompok loperamid $\mathrm{HCl}$

Tabel I. Rata-rata Rasio Panjang Usus yang dilalui Marker Norit (R) Semua Kelompok Perlakuan dan Persentase Efek Antimotilitas EEDP dan Loperamid HCl

\begin{tabular}{lccc}
\hline \multicolumn{1}{c}{ Perlakuan } & R & $\begin{array}{c}\text { Persentase } \\
\text { Antimotilitas } \\
\text { (\% penghambatan) }\end{array}$ \\
\hline Kontrol negatif PGA 10 mL/Kg BB & $0,5788 \pm 0,0209$ & - \\
Loperamid HCl 1,5 mg/KgBB & $0,2118 \pm 0,0161^{*}$ & 63,40 \\
EEDP 500 mg/Kg BB & $0,4488 \pm 0,0120^{*}$ & 22,45 \\
EEDP 1.000 mg/Kg BB & $0,3628 \pm 0,0131^{*}$ & 37,31 \\
EEDP 2.000 mg/Kg BB & $0,3220 \pm 0,0023^{*}$ & 44,36 \\
\hline
\end{tabular}

*: Hasil uji Mann-Whitney menunjukkan adanya perbedaan bermakna dengan R kelompok kontrol negatif $(\mathrm{p}<0,05)$

\section{Efek Antisekretori EEDP pada Mecit Jantan Galur Balb/C dengan Metode Castor Oil- Induced Enteropooling}

Antisekretori merupakan senyawa obat yang mampu menghambat atau mengurangi sekresi cairan dan elektrolit ke dalam usus dan merupakan salah satu golongan antidiare. Uji aktivitas antisekretori senyawa calon obat atau obat tradisional dapat dilakukan dengan menggunakan metode castor oil induced enteropooling (Formiga dkk., 2017). Dalam usus halus, castor oil akan mengalami hidrolisis dan menghasilkan asam risinoleat yang mampu merangsang mukosa usus, sehingga mempercepat gerakan peristaltik (Anwar, 2000), mengurangi absorpsi cairan, dan elektrolit, meningkatkan biosintesis prostaglandin (Akuodor dkk., 2010) serta secara langsung akan menyebabkan perubahan permeabilitas sel mukosa intestinal terhadap cairan elektrolit (Kalaskar dkk., 2010). Data efek antisekretori EEDP dalam penelitian ini adalah volume isi usus (mL). Hasil penelitian ini menunjukkan bahwa volume isi usus mencit yang mendapatkan perlakuan castor oil (kelompok negatif dengan perlakuan) mencapai $(0,730 \pm 0,046) \mathrm{mL}$, lebih besar dari pada volume isi usus mencit kelompok kontrol negatif tanpa perlakuan castor oil $(0,294 \pm 0,022) \mathrm{mL}(\mathrm{p}<0,05)$. Data ini menegaskan bahwa castor oil mampu menginduksi terjadinya peningkatan sekresi cairan dan elektrolit ke dalam lumen usus mencit jantan galur Balb/C. Perlakuan EEDP (500,1.000, dan 2.000) $\mathrm{mg} / \mathrm{kgBB}$ pada mencit jantan galur Balb/C dalam penelitian ini mampu menghambat sekresi cairan dan elektrolit ke dalam lumen usus. Rata-rata volume isi usus mencit yang mendapat perlakuan ketiga peringkat dosis EEDP tersebut berturut-turut adalah sebesar $(0,498 \pm 0,038$, $0,512 \pm 0,038$ dan $0,472 \pm 0,028) \mathrm{mL}$. Volume isi usus tersebut lebih kecil dibandingkan rata-rata 
volume isi usus mencit kelompok kontrol negatif dengan perlakuan $(0,730 \pm 0,046)(\mathrm{p}<0,05)$. Oleh karena itu, penelitian ini menyimpulkan bahwa EEDP $(500,1.000$ dan 2.000$) \mathrm{mg} / \mathrm{kgBB}$ memiliki efek antisekretori dengan persentase efek antisekretori berkisar antara (31,78-35,34)\%. Data selengkapnya tersaji pada Tabel II.

Tabel II. Rata-rata Volume Isi Usus Mencit Semua Kelompok Perlakuan setelah Mendapatkan Perlakuan 1,0 mL Castor Oil dan Persentase Efek Antisekretori EEDP

\begin{tabular}{lcc}
\hline Perlakuan & $\begin{array}{c}\text { Volume Isi Usus } \\
(\mathbf{m L})\end{array}$ & $\begin{array}{c}\text { Persentase } \\
\text { Antisekretori } \\
(\% \text { penghambatan })\end{array}$ \\
\hline KNTP & $0,294 \pm 0,022^{*}$ & - \\
KNDP & $0,730 \pm 0,046$ & - \\
EEDP 1 & $0,498 \pm 0,038^{*}$ & 31,78 \\
EEDP 2 & $0,512 \pm 0,038^{*}$ & 34,64 \\
EEDP 3 & $0,472 \pm 0,028^{*}$ & 35,34 \\
\hline
\end{tabular}

\section{Keterangan :}

KNTP :Kontrol negatif tanpa perlakuan $(\mathrm{NaCl} 0,9 \% 20 \mathrm{~mL} / \mathrm{kgBB}$

KNDP :kontrol negatif dengan perlakuan (PGA $3 \% 20 \mathrm{~mL} / \mathrm{kgBB}+$ castor oil $1,0 \mathrm{~mL})$

EEDP 1 :Ekstrak etanol daun parijoto $500 \mathrm{mg} / \mathrm{kgBB}+$ castor oil $1,0 \mathrm{~mL}$

EEDP 2 :Ekstrak etanol daun parijoto $1.000 \mathrm{mg} / \mathrm{kgBB}+$ castor oil $1,0 \mathrm{~mL}$

EEDP 3 :Ekstrak etanol daun parijoto $2.000 \mathrm{mg} / \mathrm{kgBB}+$ castor oil $1,0 \mathrm{~mL}$

(*) : Hasil uji Mann-Whitney menunjukkan adanya perbedaan bermakna dengan volume isi usus kelompok kontrol negatif dengan perlakuan $(\mathrm{p}<0,05)$

\section{KESIMPULAN}

EEDP terbukti mampu menunda terjadinya diare dan mengurangi terbentuknya feses cairtidak berbentuk pada mencit jantan galur Balb/C yang diinduksi castor oil. Mekanisme antidiare EEDP juga terungkap dalam penelitian ini melalui efeknya sebagai antimotilitas dan antisekretori.

\section{DAFTAR PUSTAKA}

Ahlquist, D.A., and Camilleri, M., 2005, Diarrhea and Constipation, diterjemahkan oleh Kasper, D.L., Fauci, A.S., Longo, D.L., Braunwald, E., Hauser, S.L., Jameson, J.L., Eds. Harrison's Principles of Internal Medicine. $16^{\text {th }}$ Ed. McGraw Hill, USA, hal. 44-49.

AHN, 2016, Medinilla speciosa L., http://www.herbalisnusantara.com/tanaman obat/5-062.pdf, diakses tanggal 27 Maret 2018

Akuodor, G.C., Usman, M.I., Ugwu, T.C., Akpan, J.L., Irogbeyi., L.A., Iwuannyanwu T.C., and Osunkwo, U.A., 2010, Ethanolic Leaf Extract of Verbena Hastata produces Antidiarrhoeal and Gastrointestinal Motility Slowin Effect in Albino Rat, J.Med. Plants Res, 4(16),16241627

Anas, Y., Fithria, R.F., Purnamasari, Y.A., Ningsih, K.A., Novianto, A.G., dan Suharjono, 2012, Aktivitas Antidiare Ekstrak Etanol Daun Randu (Ceibapetandra L. Gaern.) pada Mencit Jantan Galur Balb/C, Jurnal Ilmu Farmasi dan Farmasi Klinik, 6: 16-22.

Anggana, A. F., 2011, Kajian Etnobotani Masyarakat di Sekitar Taman Nasional Gunung Merapi, Skripsi, Institusi Pertanian Bogor, Bogor

Anwar, J., 2000, Farmakologi dan Terapi, diterjemahkan oleh Ganiswara, S.G., Setiabudy, R., Suyatna F.D., Purwantyastuti, dan Nafrialdi, Hipokrates, Jakarta hal. 61

Balaji, G., Chalamaiah, M., Ramesh, B., and Reddy, Y.A., 2012, Antidiarrhoeal Activity of Ethanol and Aqueous Extracts of Carum copticum Seeds in Experimental Rats, Asian Pacific Journal of Tropical Biomedicine, 12, 151-155

Beugerie, L. and Sokol., 2013, Acute Infectious Diarrhea in Adults: Epidemiology and Management, Presse Med. 42(1), 52-59

Chitme, H.R., Chandra, M., and Kauhik, S.,2004, Studies on Anti-diarrhoeal Activity of Calotropis gigantetea R.Br. in Ekxperimnetal Animals, J Pharm Pharmaceut Sci, 7(1), 70-75

Farthing, M., Salam, M.A., Lindberg, G., Dite, P., Khalif, I., Salazar-Lindo, E., Ramakrishna, B.S., Goh, K.L., Thomson, A. and Khan, A.G., 2013, Acute Diarrhea in Adults and Children: A Global Perspective. J. Clin. Gastroenterol. 47, 12-20 
Formiga, R.D.O., Quirino, Z.G.M., Diniz, M.D.F.F.M., Marinho., A.F., Tavares J.F., and Batista, L.M., 2017, Maytenus erythroxylon Reissek (Celastraceae) Ethanol Extract Present Antidiarrheal Activity via Antimotility and Antisecretory Mechanisms, World J Gastroenterology, 23(24), 4381-4389

Hikosaka, K., Nagamatsu, D., Ishii, H.S., and Hirose,T., 2002. Photosynthesis Nitrogen Relationships in Species at Different Altitudes on Mount Kinabalu, Malaysia, Ecological Research, 17, 305-313

Kalaskar, M.G., Divekar V.B., Chaugule P.D., Surana S.J. and Baheti D.G., 2010, Studies on AntiDiarrheal Activity of Dalberjia sissoo Roxb. in Experimental Animals, Pharmacologyonline, 1, 453-457

Katiyar, N.S., Singh, A.P., and Saravanan, K., 2015, Evaluation of Antidiarrhoeal Potential of Leaf Extract of Ocimumsanctum L. in Experimental Rats, International Journal of Pharmaceutical Sciences and Research, 6(11), 4804-4809

Komal, S.K., Rana, A.C., 2013, Herbal Approaches for Diarrhea: A Review. International Research Journalof Pharmacy, 1, 31-37

Maria, C., Buta Erszbet, Hort Denisa, 2012, Medinilla : An Exotic and Attractive Indoor Plant With Great Value, Journal of Horticulture, Foresty and Biotechnology, 16(2), 9-12

Mumpuni, K.E., Susilo, H., dan Rohman, F., 2015, Potensi Tumbuhan Lokal sebagai Sumber Belajar Biologi, Makalah, disajikan dalam Seminar Nasional XI Pendidikan Biologi FKIP UNS, Universitas Sebelas Maret, Surakarta

Sarin, R.V. and Bafina, P.A., 2012, Herbal Antidiarrhoeals, A Review, Intenational Journal of Research in Pharmaceutical and Biomedical Sciences, 637- 649

Wibowo, H.A., Wasino, dan Setyowati, D.L., 2012, Kearifan Lokal dalam Menjaga Lingkungan Hidup (Studi Kasus Masyarakat di Desa Colo Kecamatan Dawe Kabupaten Kudus), Journal of Education Social Studies, 1, 25-30 